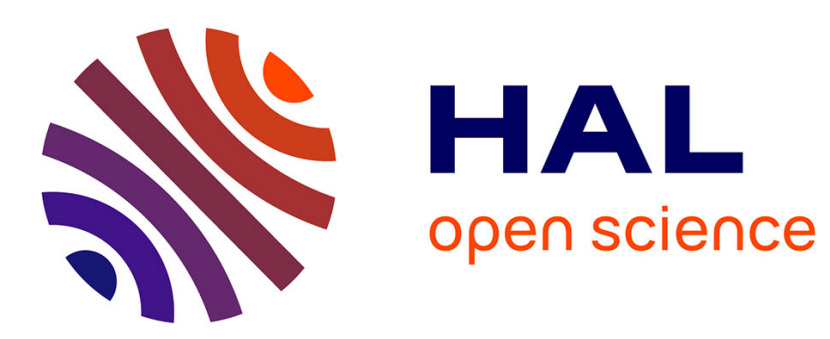

\title{
Flood mitigation designs with respect to river ecosystem functions. A problem oriented conceptual approach
}

\author{
C. Poulard, M. Lafont, A. Lenar Matyas, M. Lapuszek
}

\section{To cite this version:}

C. Poulard, M. Lafont, A. Lenar Matyas, M. Lapuszek. Flood mitigation designs with respect to river ecosystem functions. A problem oriented conceptual approach. Ecological Engineering, 2010, 36 (1), p. 69 - p. 77. 10.1016/j.ecoleng.2009.09.013 . hal-00456128

\section{HAL Id: hal-00456128 \\ https://hal.science/hal-00456128}

Submitted on 12 Feb 2010

HAL is a multi-disciplinary open access archive for the deposit and dissemination of scientific research documents, whether they are published or not. The documents may come from teaching and research institutions in France or abroad, or from public or private research centers.
L'archive ouverte pluridisciplinaire $\mathbf{H A L}$, est destinée au dépôt et à la diffusion de documents scientifiques de niveau recherche, publiés ou non, émanant des établissements d'enseignement et de recherche français ou étrangers, des laboratoires publics ou privés. 


\title{
Flood mitigation designs with respect to river ecosystem functions - a problem
}

\section{oriented conceptual approach}

Christine Poulard (1) ${ }^{*}$, Michel Lafont (2), Anna Lenar-Matyas (3), Marta Lapuszek (3)

(1): Cemagref, UR HHLY, 3 bis quai Chauveau - CP 220, F-69336 Lyon, France.

(2): Cemagref, UR BELY, 3 bis quai Chauveau - CP 220, F-69336 Lyon, France.

(3): UPK, Technical University of Cracow, IIGW, Warszawska 24, PL-31-155, Krakow, Poland

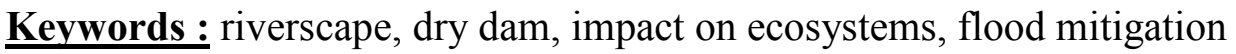

\begin{abstract}
We formulated five proposals to improve specifications of flood hazard reduction projects and five proposals to preserve the river ecosystem functions, based on literature and authors' experience. Starting from these, we established a conceptual approach using the notion of riverscape, with related function richness and bioassessment tools. We defined four riverscape types based on the gradient of artificialness, from type I (impervious bed) to type IV (less than $30 \%$ or no artificial bed). To apply our approach to dry dam designs, we individualized different parts of dry dams and characterized them by an ideal riverscape type, according to the hydraulic constraints of each part. Type I is unavoidable in the bottom outlet, and types I or II at the foot of the dam. Types III (30\% - 50\% of artificial bed) and IV were recommended at upper and lower parts of the dam, according to the risk of bank erosion and need for bank reinforcements. The approach appeared efficient to help biologists and hydraulic practitioners work together, and find technical solutions complying with both flood protection and biodiversity preservation requirement.
\end{abstract}

\footnotetext{
* corresponding author : Tel.: +33 472208792; fax.: +33 478477875; christine.poulard@cemagref.fr
} 


\section{Introduction}

Hydraulic works have been undertaken for centuries to reduce flood damages. Most of the time, the aim was to forbid overflows and ensure quick outflow of flood volumes. Rivers were channelized, diverted, straightened and corseted in levees, with little or no thoughts for river dynamics and biodiversity preservation. This approach is now widely criticized (E.U. Commission, 2004). Firstly, accelerating the flow often results in aggravating floods downstream. Secondly, the disruption of the natural patterns can disrupt the sediment balance, hence causing erosion or deposits. And finally, the consequences on ecosystems are often disastrous. How to both protect citizens from floods and biodiversity from flood-management schemes is a hot issue (Geilen et al., 2004). We advocate that biologists and hydraulic practitioners should work closely together to come up with relevant flood-protection solutions with alleviated impacts on the ecosystems.

The scope of this paper is to present the common approach we selected, with proposals for an application to the case of dry dams. The basis of the approach has to begin by a check of general concepts and proposals that can be shared both by hydraulic practitioners and biologists, and to propose several adequate operational tools, fulfilling the requirements of the proposals. We afterwards illustrate our approach on flood mitigation structures in the case of dry dam designs.

\section{Hydrology: some principles for sustainable flood management}

Scientists and policy-makers now request flood prevention policies meeting the standards of integrated and sustainable management (see for instance Gilard, 1998; Kundzewicz, 1999; E.U. Commission, 2004). Flood Management strategies must be 
devised within the framework of development plans, encompassing a larger area and scope. The new projects must comply with the program and the outcome must fit in the strategy (Plate, 2002). We selected here a few generic proposals (Poulard et al., 2009a); even if they appear common-sense, they are sometimes overlooked by project designers. P2.1. Consider all possible tools: this paper focuses on structural measures (local protections and mitigation structures), but non-structural measures (land planning, alert plans) must also be devised simultaneously, through a coordinated and long-term policy (e.g. Petrow and Thieken, 2006).

P2.2. Define reasonable and explicit objectives: the objectives should be carefully defined according to the context (peak flood reduction, local reduction of flow velocity, global damage reduction) and constraints (water body status, future development...), and explicitly stated into the specifications of projects (Plate, 2002).

\section{P2.3. Decision-makers must be provided with comprehensive information and}

objective economical evaluations, to ensure that the money is well-spent, and make it possible to compare objectively several projects.

P2.3.1. Design project and assess its effects at catchment scale. Fig. 1 illustrates a technical solution, (A), involving dykes along both sides of the river and channel enlargement, that successfully prevents flooding in one village. However, the problem is only transferred downstream, and the global economic losses could even be worsened. A study of flood hazard and vulnerability on a larger area leads rather to solution (B): floods are preferably mitigated in natural flood expansion areas or in dry dams or retention basins. Local protections and river training are kept to a minimum. 


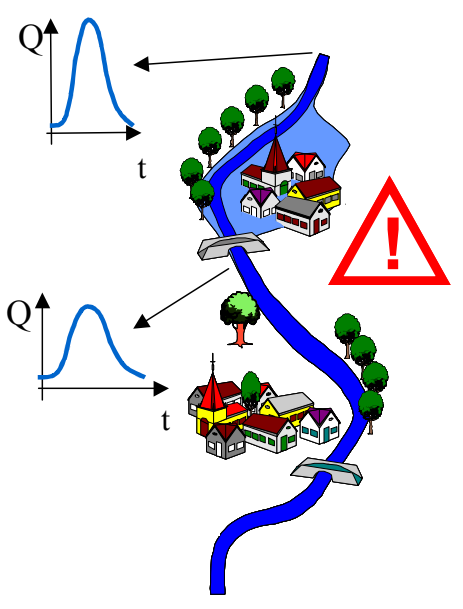

flood extent at initial state

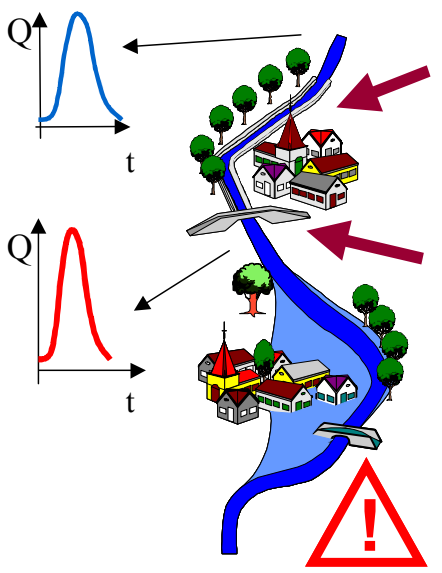

Solution (A)

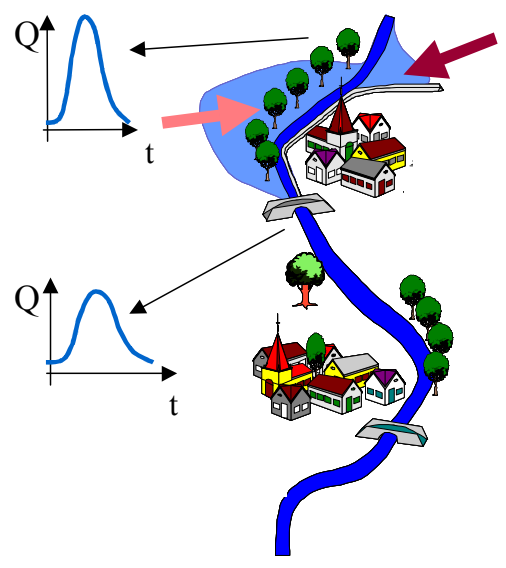

Solution (B)

Figure 1 : Local vs. catchment-scale flood mitigation measures (after Gilard, 1998)

The overall effect of all projected structures must be assessed. When several structures are spread out in the catchment, the input scenarios must be consistent over the studied area (see for instance Poulard et al., 2005; 2009b).

P2.3.2. Work at the proper time-scale: modeling can estimate the impact of the structures on one flood, and yield hydrological variables, such as flood-peak diminution or flooded area maps. Economical assessment is invaluable to compare objectively several technical solutions, taking into account the avoided damages over the life-span of the works and their cumulated costs. So, a set of floods with different probabilities must be tested to estimate first the flood extension and then finally the annualized benefit or loss. The sample of scenarios should include safety check floods - i.e. the maximum flood that the structure can withstand without risk of failure- and lowprobability but devastating dam-breaks.

P2.3.3. Assess all the consequences of the proposed solution(s), including indirect damages, such as a decrease in economical activity, as well as more intangible consequences, like impacts on resources or river ecology and functions (e.g. Loucks, 
2006). Some effects can be significant and yet very difficult to assess, such as psychological impacts (Lekuthai and Vongvisessomjai, 2001).

\section{Ecology: understanding the conditions favourable for the preservation or} restoration of the river function.

We formulated five proposals for river management, to preserve or restore the biodiversity (species richness, diversity of processes, river function...). They were issued after a bibliographic review (see for example Jones and Mulholland, 2000; Boulton, 2007; Mika et al., 2008) and our own experience (Lafont et al., 2008).

P3.1. The prerequisite suggestion is to preserve a good quality of water. It prevails on all other suggestions because if the water quality remains bad, all the benefits gained from physical rehabilitation will be lost owing to noxious pollution effects.

P3.2. Respect, where possible, the natural geomorphic context of the river course; in particular, preserve or restore the hydrologic connectivity (longitudinal, lateral and vertical) and bed sinuosity. The preservation or rehabilitation of water exchange dynamics between surface water and groundwater is essential (= vertical connectivity).

\section{P3.3. The preservation/restoration of the habitat diversity must be promoted. Porous} habitats should be preserved. They are efficient systems where water is physically and biologically filtered. But, the restoration or preservation of habitat diversity have, as far as possible, to respect the local geomorphologic situation (see P3.2).

\section{P3.4. Habitat erosion (including incision dynamics) and clogging by mineral particles} must be avoided. The integrity of bank ecotone zones (terrestrial-aquatic interface) and terrestrial environment (see also P3.5) must be preserved or restored. Artificial bank protection have to be avoided if possible, and erosion and clogging preferably limited 
when possible by natural systems like bank vegetation, and actions on surrounding land management (see P3.5).

P3.5. Limit as far as possible the imperviousness of the surrounding landscape and combined sewer overflows, which favour hydrologic stress, destruction of bank ecotone zone, clogging of porous habitats and alteration of the vertical connectivity dynamics. To fulfil the requirements of those five proposals and link our ecological approach with hydrology, we propose to take advantage of the notion of riverscape. Extent, composition and configuration of riverscapes are the main moulds that control the ecosystem processes and biodiversity (e.g. Malard et al., 2006). The riverscapes within the fluvial corridor are characterized by hydraulic connectivity, spatially and temporally heterogeneous areas with connected water bodies, dynamics of water exchanges between surface waters and groundwater, water quality and allochthonous and autochthonous nutrient fluxes (Poff et al., 1997; Jones and Mulholland, 2000; Lafont and Vivier 2006; Boulton, 2007; Malard et al., 2006; Breil et al., 2007). Consequently, the preservation or rehabilitation of the riverscape is essential for the biodiversity protection in the fluvial corridor. At the reach scale, the geomorphologic background shapes the habitats. Each habitat has its innermost physical structure which induces different nutrient cycling dynamics (Lafont, 2001). Surface porous habitats act as filters, fine deposits as accumulation systems where only a thin surficial layer biologically active is available. The hyporheic layer is an habitat where both accumulation and filtration occur. Biofilms are the bulk of the nutrient-cycling activity and the basement of biodiversity development. Benthic biofilms thrive on flat habitats, submerged logs, within porous sediment interstices, at the surface of fine sediments or macrophyte mats. Suspended biofilms develop in the water column and their metabolic role is well-known 
in lakes but somewhat underestimated in running waters (Wotton, 2007). In addition, living organisms can in return shape their close physical and chemical environments to ensure their specific feeding needs (Ostroumov, 2005). By analogy with terrestrial ecosystems (Hooper et al., 2005), the greatest nutrient cycling capacity might be sustained if the diversity of aquatic habitats remains high. If all possible habitats are present, all process dynamics are possible, from biofilms on flat habitats to complex interactions in porous sediments.

\section{Types of substrates of the riverscape at a given reach}

In un-braided rivers up to Strahler $3^{\text {rd }}$ or $4^{\text {th }}$ orders, four main types of riverscape habitats were defined (Figs. 2 and 3). Each type is illustrated by the shape of its transversal section. Type I (Fig. 2) is characterised by the simplest bed geometry and impervious surfaces. Usually, this case is encountered in urban artificial channels, but this type sometimes occurs in nature (stream-bed lying on a natural chalk cement or the rock bottom). In type IB, photosynthesis processes are possible. Benthic biofilms, invertebrates crawling on flat habitats and a few fishes can live on type I and ensure the bulk of nutrient cycling. The biofilms are composed of bacteria, algae, fungi, mosses and associated invertebrates. The system may have a quite elevated self-purification capacity, but nutrient cycling and colonization are limited to those of flat surfaces. Type II is an improvement by the addition of rough and porous habitats which stimulates the nutrient-cycling processes owing to increased contact surfaces between nutrients and biofilms (Williams and Taylor, 1968; Bou, 1977; Wotton, 2007). Diatoms and interstitial invertebrate assemblages, as well as fishes that feed on porous habitats, may be favoured too. Type III (Fig. 3) is an ecological jump as water exchanges between surface water and groundwater are, at least partially, restored. 


\section{Type I: $100 \%$ artificial channel}

Type IA: covered concrete impervious channel; (seen particularly in urbanized areas); no light.

Only biofilms (bacteria, fungi, worms, some insect larvae - mostly Diptera) living on flat habitat (benthic biofilms) or in the water (suspended biofilms); limited diversity of processes (no photosynthesis)

Type IB: uncovered impervious channel, same as above, but with photosynthesis processes; increasing diversity of processes, particularly when the bed is covered by a dense mat of aquatic mosses; fish grazing on biofilms can be present.

\section{Type II: Improved artificial channel}

$100 \%$ artificial channel but additional rough and porous blocks, providing more surface for biofilms and other living organisms; increasing diversity and efficiency of processes, in particular those related to porous habitats.
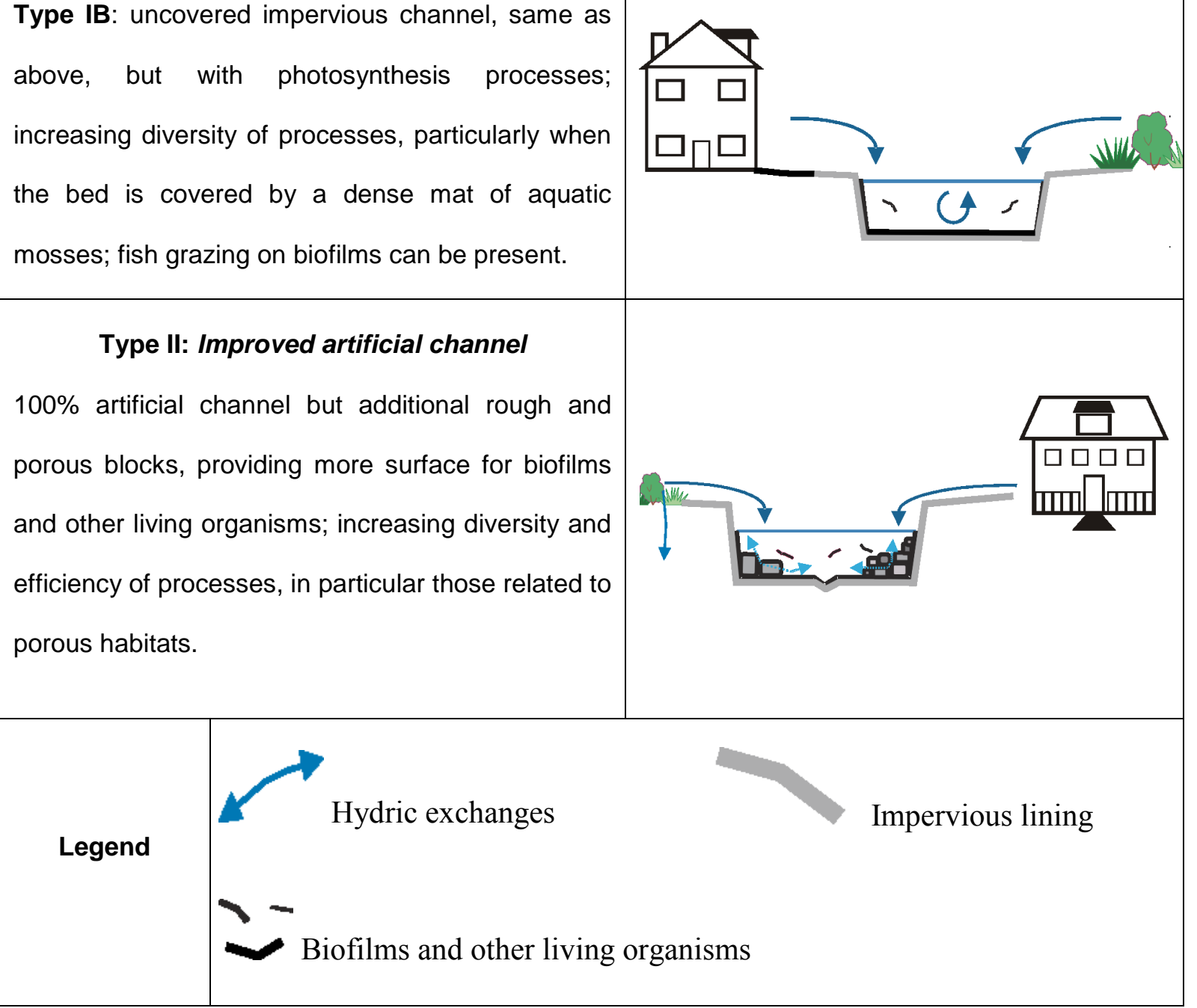

Figure 2. Types I and II of transversal sections of the local riverscape. 


\section{Type III: Semi-natural conditions}

The bed is only partially artificial, with therefore some surface-subsurface connections; increased biodiversity and diversity/efficiency of processes.

Type IIIA: artificial bed about $50 \%$; surfacesubsurface connections on part of the bed

Type IIIB: artificial bed about 30\%; surfacesubsurface connections on most of the bed

\section{Type IV: Near natural to natural conditions}

All types of habitats might be present; biodiversity richness and diversity of processes are related to the natural habitat richness, which depends on the geomorphic context; the biodiversity copes with the context if the water quality remains good

Type IVA: near-natural conditions, artificial bed = 10\%-30\% (rip-rab, gabions...)

Type IVB: natural conditions ; artificial bed $<10 \%$;

Legend

Figure 3. Types III and IV of transversal sections of the local riverscape. 
The biodiversity may theoretically increase in connection with the decrease of artificial bed percentages (from IIIA to IIIB). Type IV represents the situations occurring in nature. We shall roughly distinguish two sub-types: IVA with bank protection, IVB without any bank protection.

The following question is how to assess the biodiversity status and follow up its evolution. We suggest to follow an already existing approach (Breil et al., 2008; Lafont et al., 2008) and to select the best adapted biotic indices (here French indices) regarding the riverscape types (Table 1). If only an impervious bed is present, biomonitoring by diatom indices (IBD, AFNOR, 2007), might be relevant alone to assess the water quality effects (if the bed is not covered). The addition of artificial porous habitats (type II) allows the use of invertebrate assemblages living in coarse surface sediments, for example by using functional trait FTrs methodology (Vivier, 2006; Lafont et al., 2006). Higher habitat diversity allows to use a display of indices: IBD, functional traits FTrs, French invertebrate index (Usseglio-Pollatera et al., 2007), oligochaete index in fine sediments IOBS (AFNOR, 2002), macrophyte index in rivers IBMR (AFNOR, 2003), and fish index in rivers IPR (AFNOR, 2004). The use of operational geomorphic typologies (Schmitt et al., 2006) is necessary as soon as types III and IV of riverscapes are selected as objectives, and allow to assess the natural structure and layout of the riverscape types, which is an important feature when rehabilitation or preservation actions are planned.

\section{Application to dry dam mitigation design}

Dry dams are built across the floodplain with a bottom outlet to let the main channel flow through. Thus, only discharges above conduit capacity are modified (fig. 4). We 
described the hydrologic and civil engineering requirements, to confront them with the riverscapes typology and describe their minimum consequences on river biodiversity.
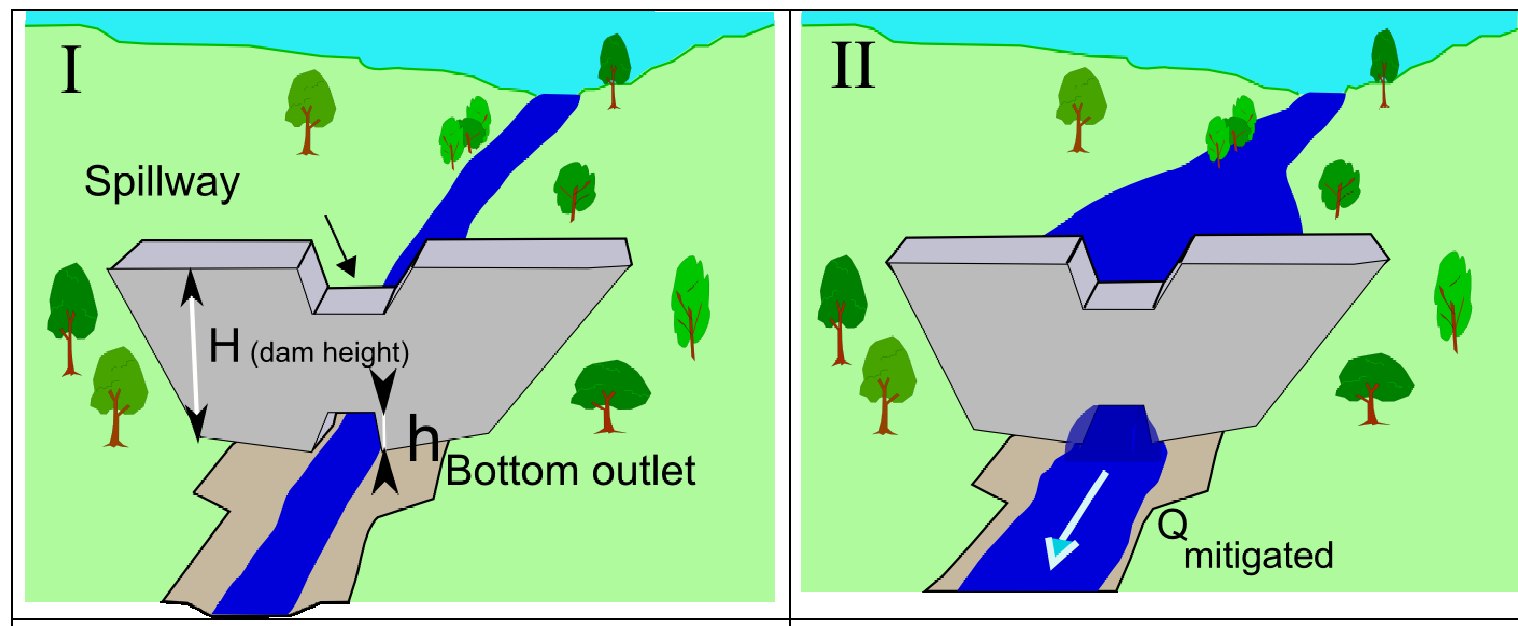

a)

b)

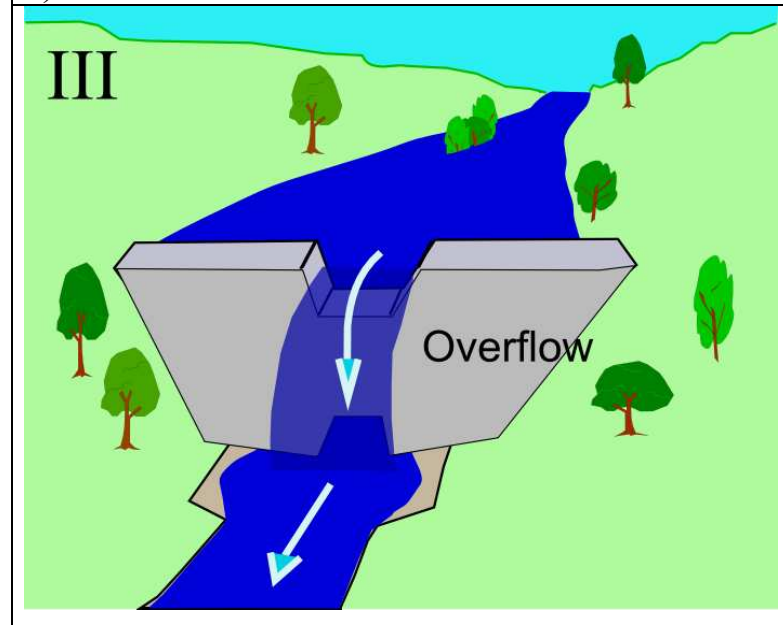

800

c)

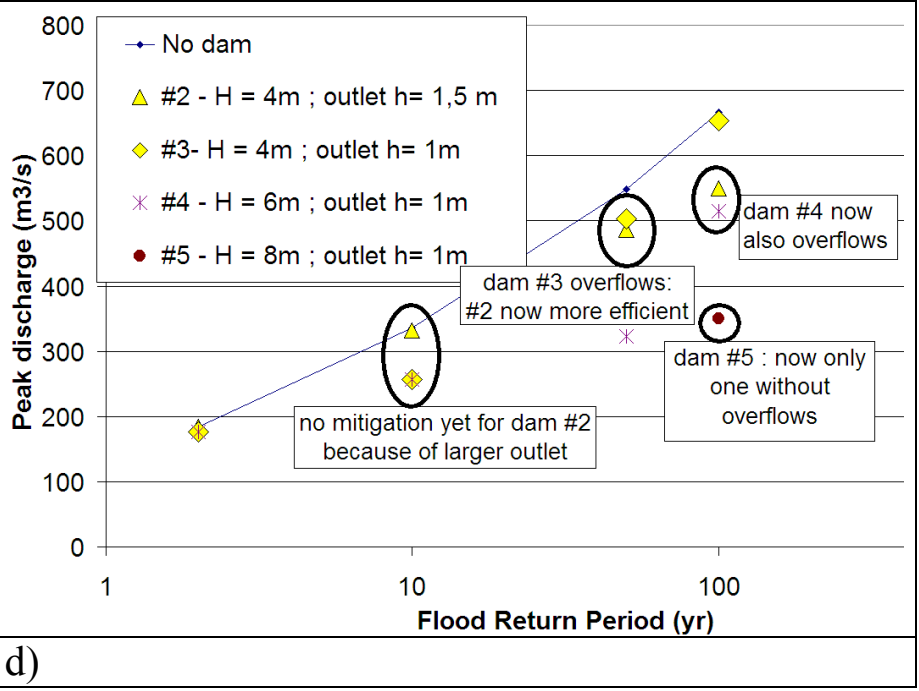




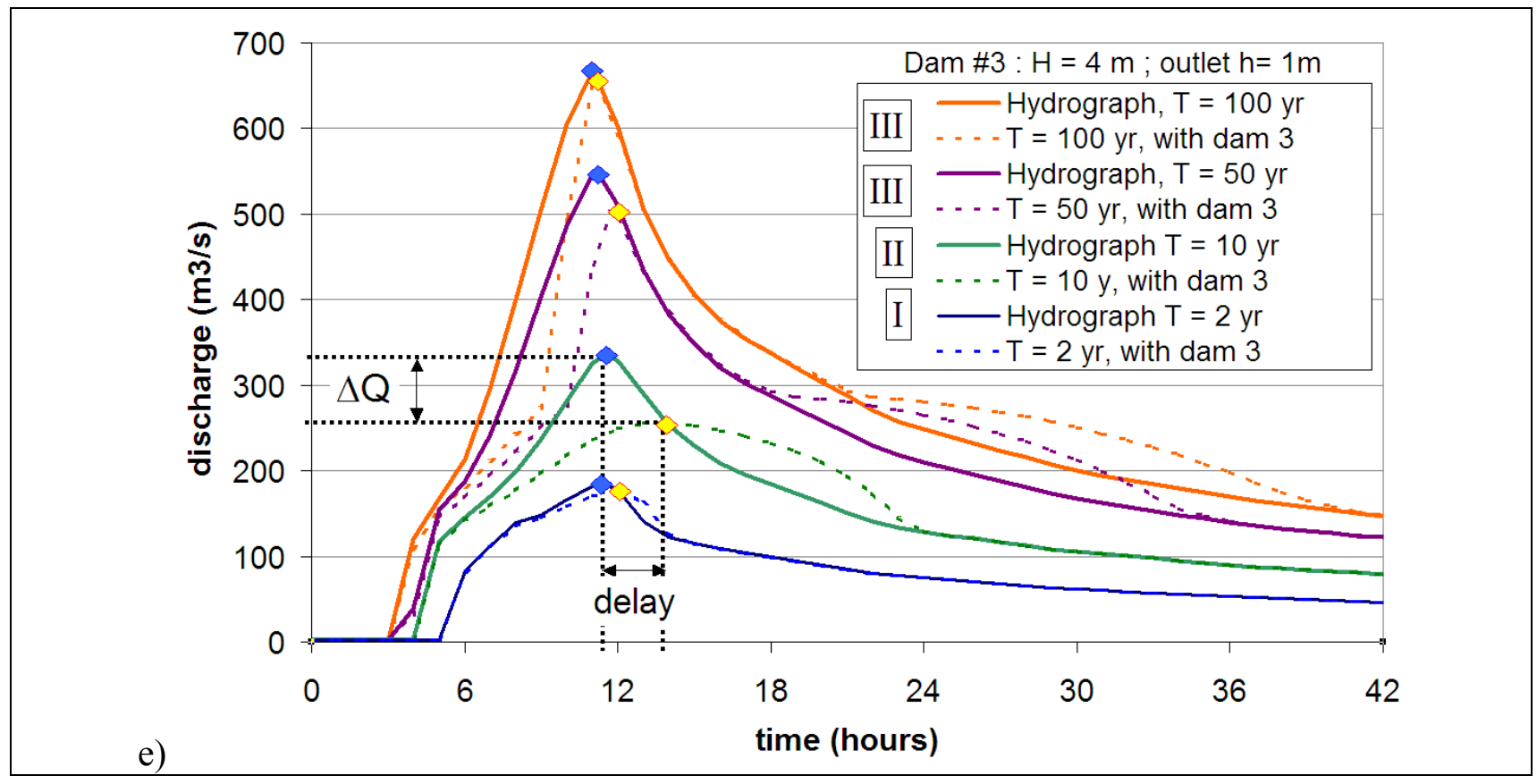

Figure 4. Principle of the effect of dry dams : $(a, b, c)$ dry dam scheme and flow patterns for increasingly large floods ; (d) synthetic peak reduction graph $v s$ estimated flood return period for 4 floods and 4 dam designs ; (e) computed hydrographs for dam \#3: delay and peak attenuation

\subsection{Dry dam design and effect on flood mitigation}

Hydrological recommendation R3.2 is particularly relevant for dry dams, because they function differently according to the flood magnitude, as shown qualitatively by Fig. 4a to c. Computations outputs are displayed in Fig. 4d and e; we used the data of Channel B2 from Ghavasieh et al. (2006) and the same hydraulic model. Results shown are taken $1.5 \mathrm{~km}$ downstream the dam. By throttle effect, dry dams reduce the peak outflow and delay the peak discharge ; however, the mitigated flood wave lasts longer (Fig. 4e). Furthermore, in some specific cases the mitigated but delayed peak may become concomitant with the peaks of other contributions, hence increasing the flood hazard downstream. 


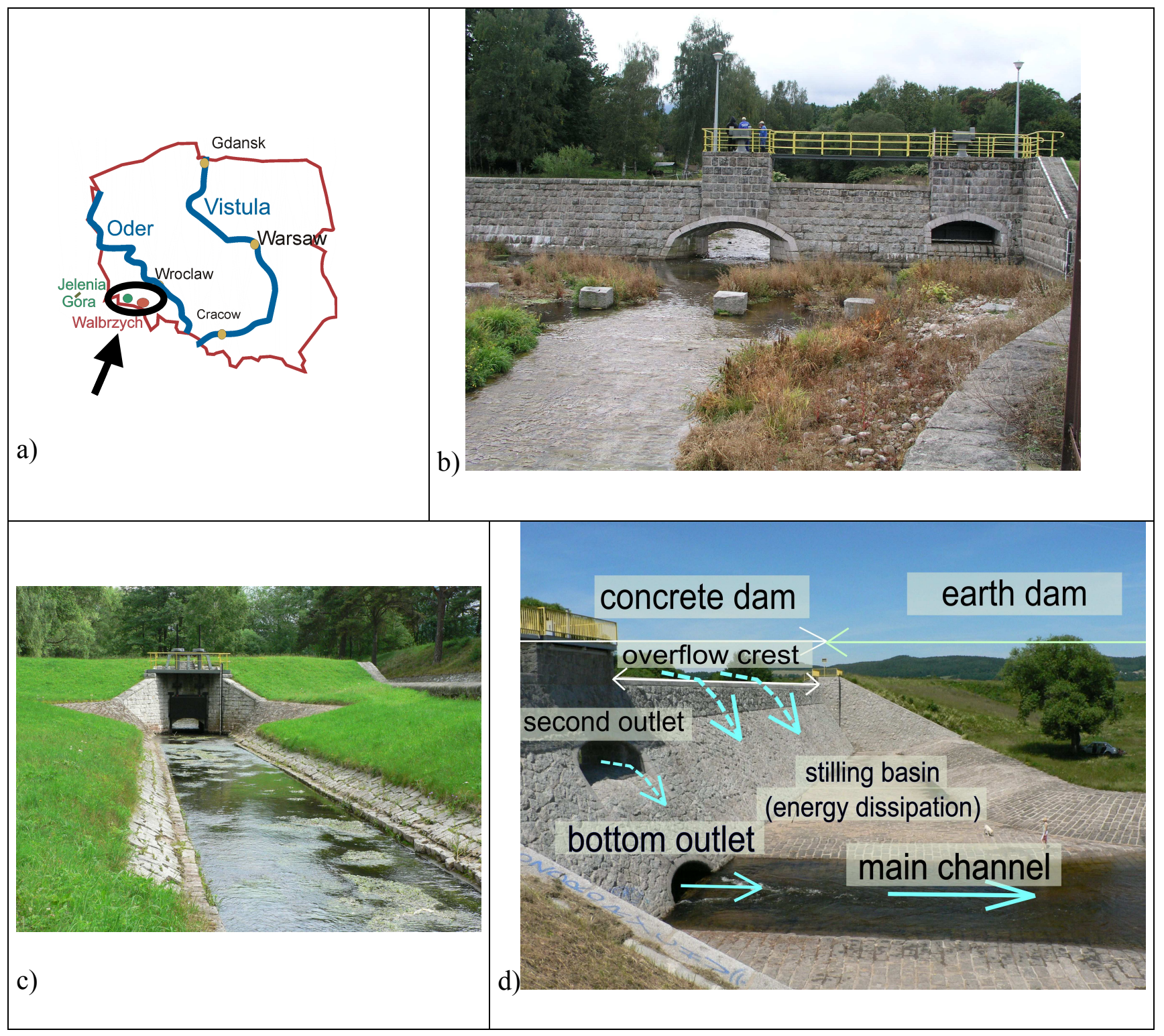

Figure 5. Example of dry dams of Silesia (built around 1910s) :

(a) location map of Jelenia Góra in Poland

(b) downstream face of Mysłakowice thin concrete dam

(c) upstream view of Krzeszów earth dam, $3.3 \mathrm{~m}$ high, storage capacity 600,000 m3, with lateral spillway

(d) Sobieszów concrete dam prolonged by earth dams in the floodplain ; 11m-high and 6.7 Mm3 storage capacity 
Mitigation characteristics depends on bottom outlet size and on the storage capacity. A smaller outlet allows earlier mitigation, thus reaching faster maximum storage capacity (compare dams \#2 and 3 on Fig. 4d). Very large floods -or two successive large floodscan fill up the storage capacity (Fig. 4c). Thus, a safety weir and overspill device must be designed to safely evacuate excess flow ; mitigation effect subsequently drops after overflows occur (Fig. 4. d and e).

Topographical constraints and safety considerations often determine the dam height. So, the design process will mainly focus on adjusting the dimensions of the bottom outlet to meet at best the specifications.

\subsection{Dry dam design constraints and zoning (Dry Dams Effect Zones)}

To limit the perturbations on the river, dry dams should be equipped by short bottom outlets of the same width and cross-section geometry as the natural river. However, mitigation and construction requirements imply to modify the natural bed in the dam's immediate vicinity. These constraints should be stated explicitly to facilitate dialog with biologists. From the observation of existing projects, and in particular the Bóbr valley dams (Fig. 5), we defined 5 zones. From upstream to downstream, they are:

Zone A: natural stretch of river upstream the dam; Zone B : the river stretch with reinforced banks upstream the dam; Zone C: the dam itself, with a bottom outlet (or a slot in some cases); Zone D: the foot of the dam; Zone A': natural stretch of river. Fig. 6 displays the proposed "Dry Dams Effect Zones" ("DDEZ") on the sketch of a dam; Table 2 lists the constraints for each zone and discusses the best possible riverscape types. In a specific project, more zones could be defined. Terrestrial zones are out of the scope of this paper, but they might be very central in some cases. For 
instance, the levees delimiting the submersible area in the fluvial corridor are artificial habitats, with their positive and negative effects. The land-use inside the bowl could be also subject to specific conservation or restorations.

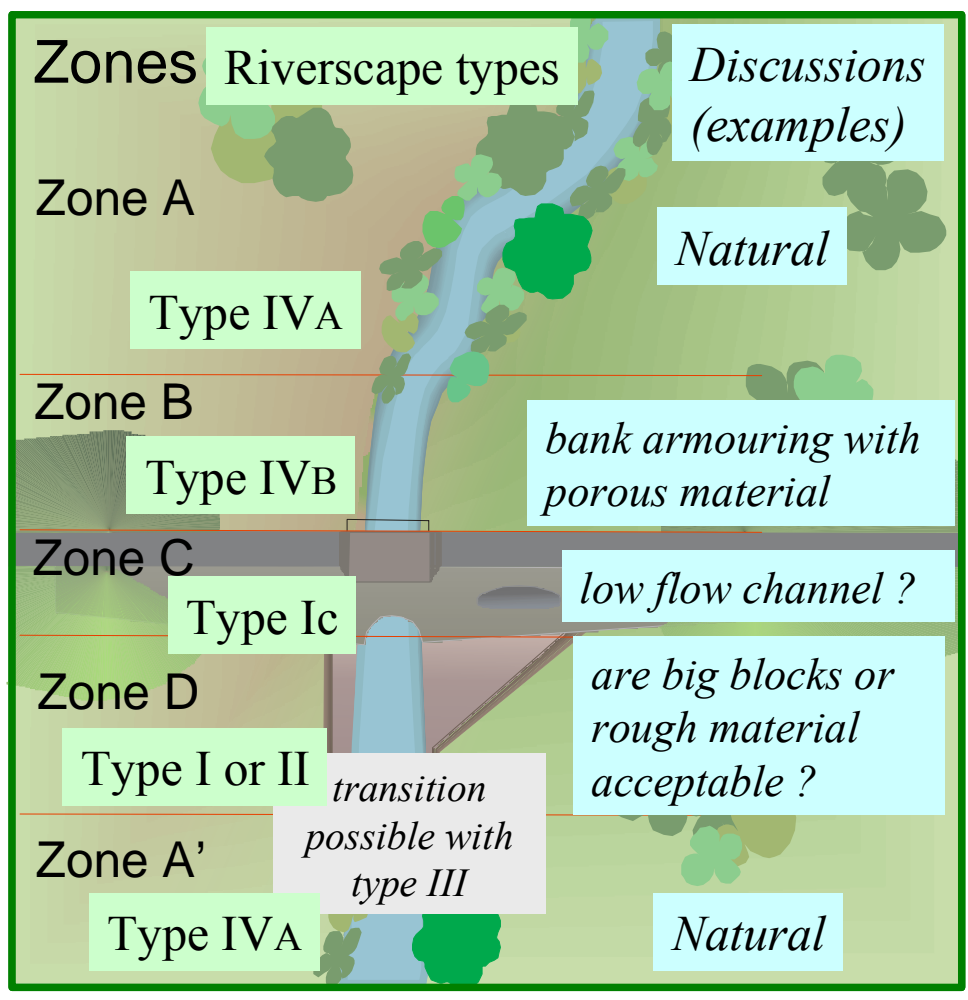

Figure 6. Plan view of a dry dam and proposed typology of "Effect Zones" -

Relationship between dry dams zones and expected riverscape type

\subsection{Examples of adapted proposals for biodiversity preservation in dry dams}

To go into further detail, we referred to the 5 proposals for biodiversity preservation, as formulated above, in the case of dry dams. For each of them, we formulated some possible technical solutions issued from our analysis (Table 3).

\section{Discussion}

This contribution proposes an approach to help defining solutions as relevant as possible, using existing tools. Indeed, managers need short-term responses and 
operational recommendations -when a flood occurs, the demand for immediate action is strong- although ecologists need time. It is thus necessary to give the managers quick responses which might be as efficient as possible. The present riverscape typology can be also applied to alleviate the drawbacks of river training in mountainous rivers (Lenar-Matyas et al. submitted). It is perfectible, open to future innovations, and involved in Ecohydrology, a fast-growing and groundbreaking domain with practical consequences (Zalewski, 2006; Zalewski and Wagner, 2008). We advocate a real involvement of all relevant disciplines, as soon as the project begins (geomorphology, terrestrial ecology, restoration skills...). Geomorphic typologies are indispensable for more in-depth studies, because they define the patchwork of riverscape types III and IV. In quite natural watercourses (type IV), some natural contexts are poor in habitats, like streams flowing on the bedrock. The purpose of the riverscape typology is not to increase the habitat richness if naturally low, but to preserve or restore a situation as far as possible close to the "natural" context, i.e. to what is presently known about local reference geomorphic (and biological) situations. Other important facets should be also taken into account. It is well-known that strong ecological interactions exist between the river and its floodplain (Amoros et al., 1987; Large et al., 1994, Mitsch et al., 2005; Hu et al., 2008...). In particular, runoff water washes pieces of dead vegetation and nutrient into the river, trees bring shade over the river and their roots often line the banks and stabilize the river, etc. The building of dry dams may affect the surrounding terrestrial ecosystems by creating flooding zones at places where floods were not necessarily frequently occurring. Linked to the time duration and water-depth of this artificial flooding, the damages to the terrestrial ecosystems, with probable consequences to the river, might be significant, by for example changing the primary and secondary ecotone 
dynamics or disturbing exchanges with the water table (Prach, 1992; Bufková and Prach, 2006). River repair is also an important facet, involving the collaboration with specialists of remediation schemes, terrestrial ecology, sociology, and aesthetics (see the review of Brierley and Fryirs, 2008). In addition, the relations between flow variability, riverscapes and biological diversity remain subject to many debates and research (see for example Biggs et al., 2005; Zalewski, 2006; Malard et al., 2006; Poff et al., 1997; 2007; Krauze et al., 2008; Mika et al., 2008; Zalewski and Wagner, 2008...). Further research on other case-studies will allow us to ameliorate our approach and to propose more sophisticated and efficient management schemes. This conceptual approach, linked to operational integrative tools, facilitates the transfer of knowledge and technical exchanges from partner to partner, and/or stimulates progress among tools developed by each partner.

\section{Acknowledgments}

Our research was partially funded by the French Ministry of Environment (MEEDDAT, Direction de l'Eau). Cooperation between French and Polish teams was made possible by funds from the EcoNet Program supported by the French Ministry of Foreign affairs. This paper owes much to many discussions with Professor Jerzy Ratomski, Dr Hanna Witkowska (UPK), and Dr Laurent Schmitt (Lyon 2 University) and with our colleagues Paul Royet, Pascal Breil and Céline Jézéquel. The authors are grateful to the two reviewers whose kind advices allowed us to significantly improve the manuscript.

\section{References}


AFNOR, 2002. Détermination de l'indice oligochètes de bioindication des sédiments (IOBS). NF T 90-390. (French standard)

AFNOR, 2003. Détermination de l'indice biologique macrophytique en rivière (IBMR). NF T90-395. (French standard)

AFNOR, 2004. Détermination de l'indice poissons en rivière (IPR). NF T90-344. (French standard)

AFNOR, 2007. Détermination de l'indice biologique Diatomées (IBD). Norme française NF T 90-354. (French standard)

Amoros, C., Roux, A.L., Reygrobellet, J.L., Bravard, J.P., Pautou, G., 1987. A method for applied studies of fluvial hydrosystems. Regulated Rivers 1, 17-36.

Biggs, B.J.F., Nikora, V.I., Snelder, T., 2005. Linking scales of flow variability to lotic ecosystem structure and function. River Res. Applic. 21, 283-298.

Bou, C., 1977. Conséquences écologiques de l'extraction des alluvions récentes dans le cours moyen du Tarn. Bull. Ecol. 8, 435-444.

Boulton, A.J., 2007. Hyporheic rehabilitation in rivers: restoring vertical connectivity. Freshwat. Biol. 52, 632-650.

Breil, P., Grimm, N., Vervier, Ph. 2007. Surface water - ground water exchange processes and fluvial ecosystem function: an analysis of temporal and spatial scale dependency. In: Wood, P.J., Hannah, D.M., Sadler, P.J. (Eds.), Hydroecology and Ecohydrology: Past, Present and Future, Chapter 6. Wiley and Sons, pp. 93-111.

Breil, P., Lafont, M., Fletcher, T.D, Roy, A., 2008. Aquatic ecosystems. In: Fletcher, T.D, Deletić, A. (Eds), Data Requirements for Integrated Urban Water Management, Chapter 20. Taylor and Francis group, London, pp. 262-272. 
Brierley, G.J., Fryirs, K.A., 2008. River futures. Island Press, p. 304.

Bufková, I., Prach, K., 2006. Linking vegetation pattern to hydrology and hydrochemistry in a montane river floodplain, the Šumava National Park, Central Europe. Wetlands Ecol. Manage. 14, 317-327.

E.U., 2000. Water Framework Directive, Directive 2000/60/CE of the European Parliament and of the Council of 23 October 2000, establishing a framework for community action in the field of Water Policy.

E.U. Commission, 2004. Best practices on flood prevention, protection and mitigation, 29 p. (http://ec.europa.eu/environment/water/flood_risk/com.htm)

Geilen, N., Jochems, H., Krebs, L., Muller, S., Pedroll, B., Van der Sluis, T., Van Looy, K., Van Rooij, S., 2004. Integration of ecological aspects in flood protection strategies: defining an ecological minimum. River Res. Applic. 20, 269-283.

Ghavasieh, A.R., Poulard, C., Paquier, A., 2006. Effect of roughened strips on flood propagation: assessment on representative virtual cases and validation. J. Hydrol. 318(14), 121-137.

Gilard, O., 1998. Guide pratique de la méthode Inondabilité. Etude Inter-Agences de l’Eau, 60, $158 \mathrm{pp}$.

Hooper, D.U., Chapin III, F.S., Ewel, J.J., Hector, A., Inchausti, P., Lavorel, S., Lawton, J.H., Lodge, D.M., Loreau M., Naeem, S., Schmid, B., Setälä, H., Symstad, A.J., Vandermeer, J., Wardle, D.A., 2005. Effects of biodiversity on ecosystem functioning: a consensus of current knowledge. Ecol. Monogr. 75, 3-35.

Hu, W., Wang, G., Deng, W., Li, S., 2008. The influence of dams on ecohydrological conditions in the Huaihe River basin, China. Ecol. Eng. 33, 233-241. 
Jones, J.B., Mulholland, P.J., 2000. Streams and Ground Waters. Academic Press, San Diego, p. 425.

Krauze, K., Zawilski, M., Wagner, I., 2008: Aquatic habitat rehabilitation: Goals, constraints and techniques. In: Wagner, I., Marsalek, J., Breil, P. (Eds.), Aquatic Habitats in Integrated Urban Water Management, Chapter 5. Urban water Series UNESCO-IHP. Taylor and Francis Group, pp 71-93.

Kundzewicz, Z.W., 1999. Flood Protection - Sustainability Issues, Hydrol. Sci. J. 44(4), 559-571.

Lafont, M., 2001. A conceptual approach to the biomonitoring of freshwater : the Ecological Ambience System. J. Limnol. 60 Suppl. 1, 17-24.

Lafont, M., Vivier, A., 2006. Hyporheic zone, coarse surface sediments and oligochaete assemblages: importance for the understanding of the watercourse functioning. Hydrobiologia 564, 171-181.

Lafont, M., Camus, J.C., Fournier, A., Sourp, E., 2001. A practical concept for the ecological assessment of aquatic ecosystems: application on the river Dore in France. Aquat. Ecol. 35, 195-205.

Lafont, M., Vivier, A., Nogueira, S., Namour, P., Breil, P., 2006. Surface and hyporheic Oligochaete assemblages in a French suburban stream. Hydrobiologia 564,183-193.

Lafont, M., Marsalek, J., Breil, P., 2008. Urban Aquatic Habitat characteristics and functioning. In: Wagner, I., Marsalek, J., Breil, P. (Eds.), Aquatic Habitats in Integrated Urban Water Management, Chapter 2. Taylor and Francis group, pp 9-24.

Large, A.R.G., Prach, K., Bickerton, M.A., Wade, P.M., 1994. Alteration of patch boundaries on the floodplain of the regulated river Trent, UK. Regul. River 9, 71-78. 
Lekuthai, A., Vongvisessomjai, S., 2001. Intangible flood damage quantification. Water Resour. Manage. 15(5), 343-362.

Lenar-Matyas, A., Łapuszek, M., Poulard, C. Alleviating the drawbacks of river training in the mountainous areas - selected examples in France and Poland. Ecol. Eng. (submitted).

Loucks, D.P., 2006. Modeling and managing the interactions between hydrology, ecology and economics. J. Hydrol. 328, 408-416.

Malard, F., Uehlinger, U., Zah R., Tockner, K., 2006. Flood-pulse and riverscape dynamics in a braided glacial river. Ecology 87; 704-716.

Mika, S., Boulton, A., Ryder, D., Keating, D., 2008. Ecological function in rivers: insights from crossdisciplinary science. In: River Futures. An Integrative Scientific approach to river repair, Brierly, G.J., Fryirs, K.A. (Eds), Island Press: 85-99.

Mitsch, W.J., Zhang, L., Anderson, C.J., Altor, A.E., Hernandez, M.E., 2005. Creating riverine wetlands: Ecological succession, nutrient retention, and pulsing effects. Ecol. Eng. 25, 510-527

Ostroumov, S.A., 2005. On the multifunctional role of the biota in the self-purification of aquatic ecosystems. Russian J. Ecol. 36, 414-420.

Petrow, T., Thieken, A. H. et al., 2006. Improvements on flood alleviation in Germany: Lessons learned from the Elbe flood in August 2002. Environ. Manage. 38(5), 717-732. Plate, E.J., 2002. Flood risk and flood management. J. Hydrol. 267(1-2), 2-11.

Poff, N.L., Allan, J.D., Bain, M.B., Karr, J.R., Prestegaard, K.L., Richter, B.D., Sparks, R.E., Stromberg, J.C., 1997. A paradigm for river conservation and restoration. BioScience. 47, 769-784. 
Poff, N.L., Olden, J.D., Merritt, D.M., Pepin, D.M., 2007. Homogenization of regional river dynamics by dams and global diversity implications. PNAS Early Edition, March 2007, 1-6.

Poulard, C., Szczesny, J., Witkowska, H., Radzicki, K., 2005. Dynamic Slowdown : A flood mitigation strategy complying with the Integrated Management concept Implementation in a small mountainous catchment. Intl. J. River Basin Management 3 (2), 75-85.

Poulard, C, Chastan, B., Royet, P., Degoutte, G., Grelot, F., Erdlenbruch, K., Nédélec, Y., 2009a. Prévention des Inondations par Ralentissement Dynamique : principe et recommandations. Ingénieries EAT, Special Issue on Flood Prevention, 5-24

Poulard, C., Leblois, L., Narbais, D., Chennu, S. 2009b. Towards objective design of dry dams at watershed scale: how to take into account the spatial structure of the rainfall and its variability, in: Hydrological extremes in small basins: 12th Biennial International Conference of the Euromediterranean Network of Experimental and Representative Basins (ERB), Kraków, Poland, 18-20 September 2008, Chelmicki, W.; Siwek, J. (Eds), UNESCO, Technical documents in Hydrology. 84, 21-28

Prach, K., 1992. Vegetation, microphotography and water table in the Lužnice River floodplain, South Bohemia, Czechoslovakia. Preslia, Praha 64, 357-367.

Schmitt, L., Valette, L., Valin, K., Piegay, H. Hallot, E., 2006. Proposition d'une méthode de typologie hydro-géomorphologique des cours d'eau et test sur un sousbassin du Rhône (bassin de l'Yzeron). Mosella XXIX, 323-340.

Usseglio-Pollatera P., Wasson, J.G., Archaimbault, V., 2007. Protocole de prélèvement et de traitement des échantillons des invertébrés sur le réseau de contrôle et de 
surveillance. République Française, Ministère de l'Ecologie et du Développement Durable, circulaire DE/MAGE/BEMA 07/n 4, p. 33.

Vivier, A., 2006. Effets écologiques de rejets urbains de temps de pluie sur deux cours d'eau périurbains de l'ouest lyonnais et un ruisseau phréatique en plaine d'Alsace. Thesis, L.P. University, Strasbourg, p. 293.

Williams, N.V., Taylor, H.M., 1968. The effect of Psychoda alternata (Say.) (Diptera) and Lumbricillus rivalis (Levinsen) (Enchytraeidae) on the efficiency of sewage treatment in percolating filters. Water Res. 2, 139-150.

Wotton, R.S., 2007. Do benthic biologists pay enough attention to aggregates formed in the water column of streams and rivers? J. N. Am. Benthol. Soc. 26, 1-11.

Zalewski, M., 2006. Ecohydrology - an interdisciplinary tool for integrated protection and management of water bodies. Arch. Hydrobiol. Suppl. 158/4, 613-622.

Zalewski, M., Wagner, I., 2008. Ecohydrology of urban aquatic ecosystems for healthy cities. In: Wagner, I., Marsalek, J.,Breil, P.(Eds.), Aquatic Habitats in Integrated Urban Water Management, Chapter 6. Taylor and Francis group, pp 95-106. 
Table 1. Adequacy between the types of riverscapes and the available biomonitoring tools; French standardized methods (IBD, IOBS, etc.) may be replaced by equivalent methods from other countries.

\section{Type I: $100 \%$ artificial channel $\rightarrow$ ecological potential}

Type IA : consideration of bacterial biofilms and possibly associated invertebrates (no standard methods) $\rightarrow$ water quality effects monitoring; not possible to define an ecological status, only an “ecological potential” can be assessed (Highly Modified Water Masses, E.U., 2000) Type IB: Diatom Index IBD, fish assemblages (few possible species), biofilms and invertebrates (see above) $\rightarrow$ water quality effects, same as above

\section{Type II: Improved artificial channel $\rightarrow$ ecological potential}

IBD, invertebrates of surface coarse sediments (functional traits FTrs), fish assemblages $\rightarrow$ not possible to define an ecological status, only an "ecological potential" can be assessed (with FTrs)

\section{Type III: Semi-natural conditions $\rightarrow$ ecological potential}

Type IIIA: artificial bed about 50\% (partially restored connections between surface and groundwater); IBD, macro-invertebrate index, FTrs of surface coarse sediments and hyporheic system (biological assessment of water exchanges between surface and subsurface), fish assemblages + harmonization system (Lafont, 2001; Lafont et al., 2001) + geomorphic tools (geomorphic assessment of water exchange between surface and subsurface); ecological potential is calculable (with FTrs)

Type IIIB: artificial bed about 30\% ; same as above + macrophyte index (IBMR) + fish index (IPR), the ecological potential is calculable (with FTrs) as well as the ecological status

\section{Type IV : Near natural to natural conditions $\rightarrow$ ecological status}

Same as above; the ecological status is calculable ; geomorphic typologies allow to define the best adapted range of biomonitoring tools. 
Table 2 Dry dam zones A, B, C, D, A' - Civil engineering constraints of dry dams and best possible riverscape types

\begin{tabular}{|c|c|c|}
\hline & Civil engineering and hydrologic constraints & Consequences on the environment and best possible riverscape types \\
\hline A & $\begin{array}{l}\text { Land-use has to be restricted in the bowl. This area may be } \\
\text { flooded only once in a few years, but near the dam water can } \\
\text { get as deep as the dam is high. Financial compensations can be } \\
\text { negotiated. Agriculture is possible. Further restrictions can be } \\
\text { imposed (e.g. ban on pesticides). Moreover, sedimentation } \\
\text { may occur locally in the bowl during emptying phase. }\end{array}$ & $\begin{array}{l}\text { Let or restore the corridor in its original status on the greatest possible } \\
\text { length; so type IV is the objective. Some of the reaches outside of the dam } \\
\text { itself might necessitate some common bank protections against floods (sub- } \\
\text { type IVA). The main expected consequences upstream the dam are on the } \\
\text { terrestrial ecosystems, not on the river itself. Consequences can be both } \\
\text { positive (preserved wild areas) and negative (severe inundations). }\end{array}$ \\
\hline B & $\begin{array}{l}\text { The river banks just upstream the dam are reinforced to funnel } \\
\text { the river into the bottom outlet and withstand higher local } \\
\text { water velocities during floods (Fig. } 5 \mathrm{c} \text { ). }\end{array}$ & $\begin{array}{l}\text { Sub-type IVA seems a reasonable goal, with reinforced but not impervious } \\
\text { banks. The river section should be left as close to possible to its natural } \\
\text { shape (see propositions in Table } 3 \text { ). }\end{array}$ \\
\hline
\end{tabular}




\begin{tabular}{|c|c|c|}
\hline $\mathcal{C}$ & $\begin{array}{l}\text { Dam foundations are indispensable, and will modify } \\
\text { groundwater circulation. Outlet size and conduit geometry and } \\
\text { slope govern the state-discharge function. The conduit will } \\
\text { withstand underpressure flows during floods. Anti-clogging } \\
\text { grids, and often anti-intrusion grids, are necessary. Grass- } \\
\text { covered earth dams often blend nicely in the landscape (Fig. } \\
\text { 5c), but concrete dams are thinner (Fig. 5b). }\end{array}$ & $\begin{array}{l}\text { The passage through the dam, whether a conduit or a slot, has to be } \\
\text { impervious; therefore nothing better than type I can be achieved. The } \\
\text { bottom outlet preserve fluxes continuity, but it is a disruption for the } \\
\text { animals, both by its geometry and material. Adaptations can improve fish } \\
\text { passage (Table 3). These proposals must be issued during the design stages, } \\
\text { so as to be taken into account into the hydraulic computations performed to } \\
\text { assess the mitigation effect. }\end{array}$ \\
\hline D & $\begin{array}{l}\text { High-energy flows will occur during floods downstream of } \\
\text { the bottom outlet and under the spillway: banks and river } \\
\text { bottom, or even part of the floodplain (Fig. 5d) have to be } \\
\text { strongly armoured, with impervious material. Stilling basins } \\
\text { or blocks (Fig. 5b) can help dissipate this energy. }\end{array}$ & $\begin{array}{l}\text { In every dam we visited, this area is definitely type I. Additional porous } \\
\text { substratum could upgrade it to type II. Heavy blocks or blocks cemented to } \\
\text { the banks could also help absorb the high-energy flows but may decrease } \\
\text { the evacuation capacity. The effects of stilling basins were not investigated. }\end{array}$ \\
\hline $\boldsymbol{f}^{\prime}$ & $\begin{array}{l}\text { The river may be left alone again, if necessary after a transition } \\
\text { zone more moderately artificialised. The flood regime in zone } \\
\mathrm{A}^{\prime} \text { is modified by the dam, over a long distance. }\end{array}$ & $\begin{array}{l}\text { Type IV must be preserved or restored as soon as it is physically possible, if } \\
\text { necessary after transition stages (type II to type III). Key habitat parameters } \\
\text { are impacted by regime modification (Hu et al., 2008) }\end{array}$ \\
\hline
\end{tabular}


Table 3: Example of technical solutions complying with biological requirements, after proposals P3.1 to P3.5 for biodiversity preservation.

\begin{tabular}{|c|c|}
\hline Five proposals & Examples of technical solutions \\
\hline Good quality of waters & ewage treatments; limitation of inputs; land-use restrictions in the bowl; limit/eradicate CSOs (see P3.5) \\
\hline $\begin{array}{l}\text { Longitudinal, lateral, } \\
\text { vertical connectivities }\end{array}$ & $\begin{array}{l}\text { Avoid dykes, allow overflows to floodplain wherever possible, do not close the stream-bed. Short bottom outlets } \\
\text { are preferable. Include low-flow channels where relevant and where it is compatible with the mitigation } \\
\text { requirements. Natural-looking material is preferable to smooth surfaces to limit water velocity and also for } \\
\text { aesthetics. Avoid steps, which may be impassable for small fishes, particularly when they create a transverse } \\
\text { eddy. Armouring and impervious lining should be limited to what is absolutely necessary. }\end{array}$ \\
\hline Habitat diversity & $\begin{array}{l}\text { Regular geometrical shapes should be avoided in long reaches. Even in channelized stretches, irregular cross- } \\
\text { sections and varied slopes are preferable, with for instance riffle and pools succession, to be designed according } \\
\text { to the local geomorphologic patterns. }\end{array}$ \\
\hline $\begin{array}{l}\text { Limit habitat and bank } \\
\text { erosion and siltation }\end{array}$ & $\begin{array}{l}\text { Bank protections only where necessary (with permeable material if possible). In areas of high sediment deposits, } \\
\text { be careful if the dam bowl is too narrow: sediments will be stored leading to clogging by thick deposits. }\end{array}$ \\
\hline $\begin{array}{l}\text { Limit imperviousness } \\
\text { and CSOs }\end{array}$ & $\begin{array}{l}\text { Restrict or limit (if possible!) the urbanisation of the surrounding landscape and the building of highways, avoid } \\
\text { armouring/lining (see also proposal P3.2); build decantation-filtrations basins for CSOs and separate sewers... }\end{array}$ \\
\hline
\end{tabular}




\section{Caption to figures}

Figure 2 : Local vs. catchment-scale flood mitigation measures (after Gilard, 1998)

Figure 2. Types I and II of transversal sections of the local riverscape.

Figure 3. Types III and IV of transversal sections of the local riverscape.

Figure 4. Principle of the effect of dry dams : $(a, b, c)$ dry dam scheme and flow patterns for increasingly large floods ; (d) synthetic peak reduction graph $v s$ estimated flood return period for 4 floods and 4 dam designs ; (e) computed hydrographs for dam \#3: delay and peak attenuation

Figure 5. Example of dry dams of Silesia (built around 1910s) :

(a) location map of Jelenia Góra in Poland

(b) downstream face of Mysłakowice thin concrete dam

(c) upstream view of Krzeszów earth dam, 3.3 m high, storage capacity 600,000 m3, with lateral spillway

(d) Sobieszów concrete dam prolonged by earth dams in the floodplain ; 11m-high and 6.7 Mm3 storage capacity

Figure 6. Plan view of a dry dam and proposed typology of "Effect Zones" Relationship between dry dams zones and expected riverscape type 